DOI: https://doi.org/10.47405/mjssh.v6i9.1056

\begin{tabular}{|c|c|}
\hline 4 & Malaysian Journal of Social Sciences and Humanities (MJSSH) \\
\hline $\begin{array}{l}\text { Malaysian Juoural of } \\
\text { Social ccciecces and }\end{array}$ & Volume 6, Issue 9, September 2021 \\
\hline (MJ-sSH) & e-ISSN : 2504-8562 \\
\hline & $\begin{array}{l}\text { Journal home page: } \\
\text { www.msocialsciences.com }\end{array}$ \\
\hline
\end{tabular}

\title{
Factors Influencing Purchase Intention of Elancing Using UTAUT Model: A Case Study of Mahajasa
}

\author{
Hanifah Dwi Adiratna ${ }^{1}$, Amilia Wulansari1 \\ ${ }^{1}$ School of Business and Management, Bandung Institute of Technology, Indonesia \\ Correspondence: Hanifah Dwi Adiratna (hanifah_dwi@sbm-itb.ac.id)
}

\begin{abstract}
Technology advancements have given rise to a new labor market mechanism known as elancing, where people could purchase freelance services through online sites. Following the trend, Mahajasa as a freelance marketplace startup has to compete with other existing competitors in Indonesia. Established for a year, fluctuating revenue and unknown intention of buying is incurred. Mahajasa aims for SMEs and students across Indonesia. But some recent studies stated that SMEs in Indonesia are reluctant to accept new technology since most marketplaces are in the adoption stage. This study's main objective is Understanding the most influential factors of purchase intention in buying services from freelance marketplace or freelance social media using UTAUT model. The research concluded 386 respondents from Indonesia who had used elancing platforms aged 15-44 years old and analyzed using SmartPLS. The result showed performance expectancy, effort expectancy, social influence, and perceived trust has a positive impact on purchase intention. While perceived trust has a partial mediating role between performance expectancy, effort expectancy, and social influence to purchase intention.
\end{abstract}

Keywords: elancing, purchase intention, UTAUT, Indonesia

\section{Introduction}

In today's world, connectivity from the worldwide web has been influencing most of our lives including companies. Indonesia has an outstanding pace of digitalization and technology advancement. Based on We Are Social data, each year from 2015, the penetration rate increased with average above $10 \%$. This tremendous number is the impact of the rising number of online activities due to pandemic COVID-19. Abubakar and Shneikat (2017) stated that technology advancements have given rise to a new labor market mechanism known as electronic lancing (elancing). Full-time employment is diminishing gradually and short term employment such as freelancers and internships is rising dramatically (Tench, Fawkes, \& Palihawadana, 2002).

The growing popularity of elancing has been the inspiration for Indonesia to have their own freelancing marketplace such as sribulancer.com, fastwork.com, sejasa.com, projects.co.id and others. The Central Statistics Agency (BPS) noted that as many as 33.34 million people worked part-time or freelancers as of August 2020. This number increased by 26\% from the year before. Because of the high market potential, it gave the opportunity to run a new freelancing marketplace in Indonesia. Freelancing marketplace is the act of outsourcing work through online platforms for employment. Nowadays, not just for freelancers but also for freelancing platforms, the e-lancing market is becoming more competitive. 
Mahajasa is one of the players in the freelance marketplace industry in Indonesia. In this study, the author focused on solving problems inside the company and gave an implementation plan for them. Most marketplace and e-commerce in Indonesia is still in its early stages (adoption), thus most Indonesian customers find online purchasing difficult (Ariyanti, 2017). It is strengthened also by Gambetta and Syuhada (2013) studies that due to a lack of technological readiness, the majority of SMEs in Indonesia have been unable to fully embrace E-Commerce or marketplace. Therefore, there's urgency to understand Indonesians market technology acceptance especially in e-lancing and the author used the UTAUT framework.

\section{LITERATURE REVIEW}

\section{Elancing}

Elancing platforms offer a virtual marketplace which could be described as a "website where people who are interested in being employed and employers seeking individuals to perform some sort of work meet" (Aguinis \& Lawal, 2013). In e-lancing, the employer may be a person, a corporation, or a small business, and is commonly referred to as the 'Client.' E-lancing could be performed in two ways, which are through marketplace and through social media. Both of the platforms were different in customer journey but have the same purpose. The freelance marketplace and social media have the same role as a means of buying and selling professional services that have the potential to help, even support Indonesia's gig worker economy (Pratama, 2021).

\section{Purchase Intention}

Purchase is the act of someone exchanging their money with a product or services. Before purchasing, there are a lot of things to be considered for them to decide, it is complex and complicated. Consumers tend to compare and already have choices with various reasons or could be called as intentions. Purchase intention is defined as consumers' willingness to buy certain products or services (Ailawadi, Neslin, \& Gedenk, 2001). Online purchase intention refers to the consumers' willingness to be involved in an online transaction (Pavlou, 2003).

\section{UTAUT (Unified Theory of Acceptance and Use of Theory)}

UTAUT was created after a thorough review of past technology acceptance and use studies (Venkatesh et al., 2003). UTAUT derived from various theoretical foundations for system use determinants such as TAM (Davis et al., 1989), TRA (Fishbein \& Ajzen, 1975), social cognitive theory (Compeau et al., 1999), innovation diffusion theory (Moore \& Benbasat, 1991), motivational model (Davis et al., 1992), and model of PC utilization (Thompson et al., 1991). Performance expectancy, effort expectancy, social influence, and facilitating conditions are the four dimensions with primary effects on behavioral intention. Those predictors, based on the framework, influence behavioral intention and usage of technology. The model was chosen in this study because it has a benefit in terms of understanding why people are willing to use specific technologies. According to Venkatesh et al. (2003), this model explains $70 \%$ of technological acceptance, whereas previous models could only answer approximately $40 \%$. UTAUT has been used for various purchase intentions research (Doan, 2020; Chen et al., 2021).

\section{Performance Expectancy}

The degree to which an individual feels that adopting the tool will assist them in improving work performance is referred to as performance expectancy (Venkatesh, 2003). Performance expectation is the best predictor of attitude toward usage and behavioral intentions, according to Jeng and Tzeng (2012). Therefore, in this study the author indicated that performance expectancy positively influences the purchase intention. 


\section{Effort Expectancy}

The degree of easiness involved with using the system is referred to as effort expectancy. This means that effort expectancy refers to the effort needed to use the system, whether it is simple or complicated (Catherine et al., 2017). The idea of effort expectation is captured by three components from current models: ease of use (IDT), perceived ease of use (TAM/TAM2), and complexity (MPCU). In this study context, effort expectancy means perception of customers' ease of e-lancing using freelance marketplace or freelance social media.

\section{Social Influence}

The degree to which a person believes important individuals believe he or she should use the new method is referred to as social influence. Subjective norms in TRA, TAM2, TPB/DTPB, and C-TAMTPB, social factors in MPCU, and image in IDT all indicate social impact as a direct driver of behavioral intention. According to previous study, people are more willing to agree with others' expectations when those relevant others have the capacity to influence or reprimand noncompliance (French \& Raven, 1959). In elancing context, social influence implies that consumer's intention to buy will increase if proper publicity builds a positive image of the freelancing sites.

\section{Perceived Risk}

Consumer perceptions of uncertainty and unfavorable outcomes that may result from the acquisition of a product or service are referred to as perceived risk (Oglethorpe \& Monroe, 1994). Pavlou (2003) stated that consumers' intentions to use e-commerce for transactions are predicted to be hindered as a result of their perception of risk. As a new form of employment, the elancing platform presents consumer concerns about service quality, delivery timeliness, payment security, and other issues. As a result, the author hypothesized that perceived risk had a negative influence on purchase intention.

\section{Perceived Trust}

Trust definition is complex and there is no universally accepted and fixed definition of trust. Based on various dictionaries (Oxford, Merriam-Webster) trust means confidence, expectations, and hope. In Chen et al. (2021) model, Perceived trust becomes a mediator role for consumers' performance expectations, effort expectancy, social influence, and perceived risks toward purchase intention. Consumers' perceived trust and perceived risk strongly influenced their decisions when purchasing through the Internet (Kim, Ferrin \& Rao, 2008). In line with the gap in conventional freelancers and online freelancers, the author assumed that personal trust would have a significant impact on purchase intention.

\section{Hypothesis and framework}

H1: Performance expectancy has a direct positive and significant impact on purchase intention.

$\mathrm{H} 2$ : Effort expectancy has a direct positive and significant impact on purchase intention.

H3: There is a direct positive and significant impact on the purchase intention at social influence.

H4: Purchase intention has a strongly negative influence/impact on perceived risk.

H5: Perceived trust plays a significant mediator role between performance expectancy and purchase intention.

H6: Perceived trust plays a significant mediator role between effort expectancy and purchase intention.

H7: Perceived trust plays a significant mediator role between social influence and purchase intention.

H8: Perceived trust plays a significant mediator role between perceived risk and purchase intention. 
Figure 1: Research Framework

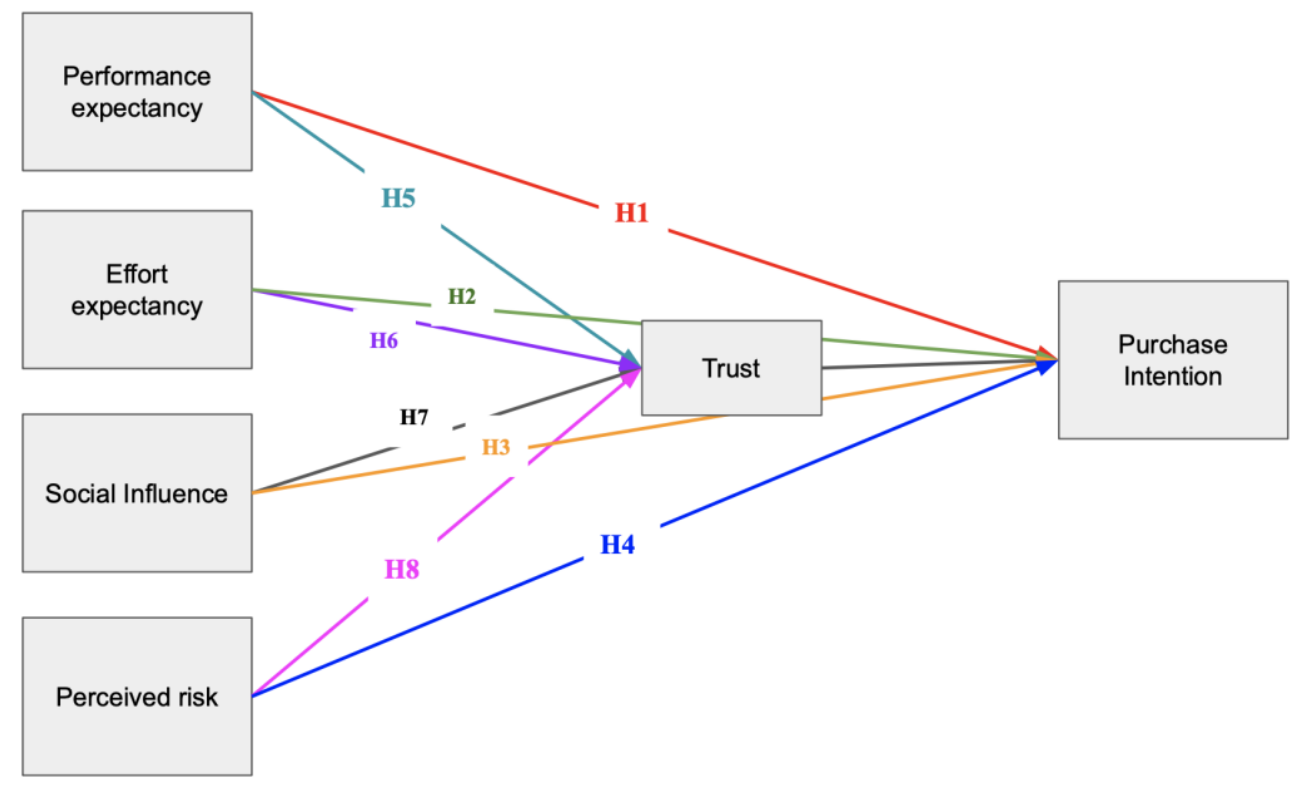

\section{Methods}

\section{Research Design}

This research was conducted in a problem-solving method. The layout of this study is as shown in Figure $\mathrm{xx}$, with the first step being to define the issue that has been occurring in Mahajasa in terms of doing business, which is fluctuating revenue. The theory was then formed into a hypothesis and became a conceptual construct after a literature analysis of the customer segmentation and purchase intention from previous research. The hypothesis was then turned into variables, which were used to create a questionnaire to gather data from respondents and analyze it using PLS-SEM to address the research question. Following the study, the results will be distilled into some key takeaways. Then, the author turned the interpretation into an implementation plan for Mahajasa as a business solution. Finally, given the conclusion and recommendations for further research.

Figure 2: Research Design

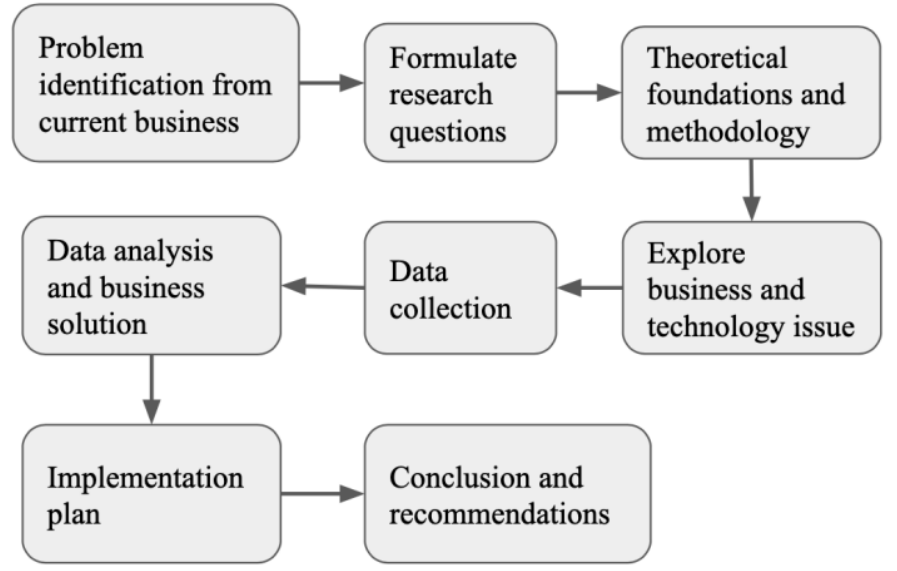

In this study, the author chooses to use a quantitative method in order to complete the research design above. Objectives of this research are testing the possible variables that influence purchase intention of specific customer segments using the UTAUT model, so that the author could understand what factors influence the purchase intention of freelance services through online platforms. To collect the primary data, the author uses online surveys or questionnaires based on various researches. The total 
population size for this study is approximately 27 million people considering $70 \%$ of the population of each area is productive age. For this study, the author used Slovin's formula with 95\% confidence interval or 0.05 error. Therefore, the minimum sample size would be 385 respondents.

SmartPLS 3.0 was used for testing the measurement model and PLS-SEM (Partial least squares structural equation modeling). Sampling in this study using a Likert scale questionnaire. The Likert scale implied by (1) Strongly Disagree, (2) Disagree, (3) Neutral, (4) Agree, and (5) Strongly Agree. It defines how they think they agree or disagree with the term given.

\section{Results}

\section{Convergent}

The Fornell-Larcker (1981) measure has been widely used to assess the degree of shared variance across the model's latent variables. The Average Variance Extracted (AVE) and Composite Reliability can be used to examine the measurement model's convergent validity according to this criterion (CR). The acceptable values for both AVE and CR are 0.7 or above. Based on table 1 . it is shown that all variables are valid because all of the values have surpassed 0.7 .

Table 1: Validity

\begin{tabular}{lll}
\hline & Average Variance Extracted & Validity \\
\hline Perceived trust & 0.8 & Valid \\
Performance expectancy & 0.651 & Valid \\
Purchase intention & 0.747 & Valid \\
effort expectancy & 0.714 & Valid \\
perceived risk & 0.638 & Valid \\
social influence & 0.716 & Valid \\
\hline
\end{tabular}

\section{Discriminant validity}

The degree to which latent variable A distinguishes itself from other latent variables is known as discriminant validity. Discriminant validity (also known as divergent validity) examines whether constructs that should be unrelated are, in fact, unrelated. According to Fornell and Larcker (1981), discriminant validity could be measured by square root of variables or using Heterotrait-monotrait ratio of the correlations (HTMT) while in this study the author chose the criterion in Fornell Larcker. Each latent variable's square root of AVE should be larger than the correlations among the latent variables.

Table 2: Discriminant validity

\begin{tabular}{llllll}
\hline & $\begin{array}{l}\text { Perceived } \\
\text { Trust }\end{array}$ & $\begin{array}{l}\text { Performance } \\
\text { Expectancy }\end{array}$ & $\begin{array}{l}\text { Purchase } \\
\text { Intention }\end{array}$ & $\begin{array}{l}\text { Effort } \\
\text { Expectancy Risk }\end{array}$ & $\begin{array}{l}\text { Perceived Social } \\
\text { Influence }\end{array}$ \\
\hline $\begin{array}{l}\text { Perceived Trust } \\
\text { Performance }\end{array}$ & $\mathbf{0 . 8 9 5}$ & & & \\
Expectancy & 0.585 & $\mathbf{0 . 8 0 7}$ & & \\
Purchase Intention & 0.581 & 0.605 & $\mathbf{0 . 8 6 5}$ & \\
Effort Expectancy & 0.62 & 0.739 & 0.623 & $\mathbf{0 . 8 4 5}$ \\
\hline
\end{tabular}


DOI: https://doi.org/10.47405/mjssh.v6i9.1056

\begin{tabular}{lllllll}
\hline Perceived Risk & 0.212 & 0.371 & 0.264 & 0.346 & $\mathbf{0 . 7 9 9}$ & \\
Social Influence & 0.462 & 0.448 & 0.439 & 0.469 & 0.304 & $\mathbf{0 . 8 4 6}$ \\
\hline
\end{tabular}

All of the latent variables' AVE square roots are bigger than their correlation values, as seen in table 2 marked by green colored values. As a result, all variables passed the discriminant validity test and thus can follow the steps.

\section{Internal consistency reliability}

Internal consistency is a metric that assesses whether various items on the same test have comparable correlations and hence give similar results or not. The majority of researchers use Cronbach's alpha which is a statistic generated from pairwise correlations between items. But Cronbach's alpha requires only a single test administration to provide a unique estimate of the reliability for a given test, which is considered insufficient (Gliem \& Gliem, 2003). Because of the limits of Cronbach's alpha, it is more acceptable to use composite reliability. A composite reliability of more than 0.70 is desirable. Cronbach's alpha as the lower constraint for internal consistency reliability and composite reliability as the upper limit (Hair, 2017). In table 3, All of the Cronbach's alpha values and composite reliability values have fulfilled the desirable measurement, therefore all of the variables are reliable.

Table 3: Internal consistency reliability

\begin{tabular}{llll}
\hline & Cronbach's Alpha & Composite Reliability & Reliability \\
\hline Perceived Trust & 0.875 & 0.923 & Reliable \\
Performance Expectancy & 0.821 & 0.882 & Reliable \\
Purchase Intention & 0.831 & 0.899 & Reliable \\
Effort Expectancy & 0.866 & 0.909 & Reliable \\
Perceived Risk & 0.72 & 0.84 & Reliable \\
Social Influence & 0.802 & 0.883 & Reliable \\
\hline
\end{tabular}

\section{Indicator Reliability}

The percentage of indicator variation explained by the hidden variable is known as indicator reliability. The range of values is 0 to 1 .

Table 4: Indicator Reliability

\begin{tabular}{llllll}
\hline & PE1 & 0.783 & & SI1 & 0.844 \\
& PE2 & 0.844 & & SI2 & 0.862 \\
& PE3 & 0.84 & Social Influence & SI3 & 0.832 \\
Performance Expectancy & PE4 & 0.758 & & PT1 & 0.899 \\
& EE1 & 0.816 & & PT2 & 0.907 \\
& EE2 & 0.864 & Perceived Trust & PT3 & 0.877 \\
Effort Expectancy & EE3 & 0.865 & & PI1 & 0.863 \\
Perceived Risk & EE4 & 0.833 & & PI2 & 0.876 \\
\hline
\end{tabular}




\section{PR2 0.832}

PR3 0.843

The outer loadings value should be more than 0.70 , and it should be evaluated for deletion if removing an indication with outer loadings between 0.40 and 0.70 increases composite reliability and average variance extracted (AVE) (Hair, 2017). Indicators with an outside loading of less than 0.40 , on the other hand, should always be deleted (Hulland, 1999). The outer loadings investigate each indication in variables to identify that the respective indications were eligible or not. Using the SmartPLS algorithm, there's only one indication labeled as PI4 from the Purchase intention variable which doesn't meet the expectation so the author removed it. Based on the table 4, the remaining values have exceeded 0.7 which means it is reliable and we could pursue the next step.

\section{Model fit measures}

The difference between the observed correlation and the model indicated correlation matrix is defined as the SRMR. As a result, it's possible to use the average size of the differences between observed and anticipated correlations as an absolute measure of (model) fit. A good fit is defined as a number less than or equal to 0.10 or 0.08. (Hu and Bentler, 1998). Henseler et al. (2014) presented the SRMR as a goodness of fit metric for PLS-SEM that may be used to avoid model measurement error in recent research. Table 5 represents the SRMR results for the model. Both the saturated model and estimated model are indicating that the model is sufficient and has a good fit.

Table 5: SRMR result

\begin{tabular}{lllll}
\hline & Original Sample (O) & Sample Mean (M) & $\mathbf{9 5 \%}$ & $\mathbf{9 9 \%}$ \\
\hline Saturated Model & 0.062 & 0.04 & 0.044 & 0.046 \\
Estimated Model & 0.062 & 0.04 & 0.044 & 0.046 \\
\hline
\end{tabular}

\section{Hypothesis analysis}

\section{H1: Performance expectancy has a direct positive and significant impact on purchase intention}

Performance expectancy confirmed that is has direct positive and significant impact on purchase intention. The $\mathrm{t}$ value is 4.21 which is higher than 1.96 and the p-value is 0.000 so the hypothesis 1 is accepted

Table 6: Hypotheses result $\mathrm{H} 1-\mathrm{H} 4$

\begin{tabular}{|c|c|c|c|c|c|c|}
\hline Structural path & $\begin{array}{l}\text { Original } \\
\text { Sample (O) }\end{array}$ & $\begin{array}{l}\text { Sample Mean } \\
\text { (M) }\end{array}$ & STDEV & T Statistics & P-Value & Decision \\
\hline $\begin{array}{l}\text { Performance } \\
\text { expectancy -> } \\
\text { Purchase intention }\end{array}$ & 0.225 & 0.224 & 0.077 & 2.922 & 0.003 & Accepted \\
\hline $\begin{array}{l}\text { Effort expectancy -> } \\
\text { Purchase intention }\end{array}$ & 0.256 & 0.256 & 0.071 & 3.581 & 0.000 & Accepted \\
\hline $\begin{array}{l}\text { Perceived risk -> } \\
\text { Purchase intention }\end{array}$ & 0.01 & 0.013 & 0.041 & 0.232 & 0.816 & Rejected \\
\hline $\begin{array}{l}\text { Social influence -> } \\
\text { Purchase intention }\end{array}$ & 0.104 & 0.105 & 0.048 & 2.183 & 0.029 & Accepted \\
\hline
\end{tabular}




\section{H2: Effort expectancy has a direct positive and significant impact on purchase intention}

The table 6 confirmed that Effort expectancy has a direct positive and significant impact on purchase intention. The $\mathrm{t}$ value is 3.58 which is higher than 1.96 and the p-value is 0.000 so the hypothesis 2 is accepted

\section{H3: Social influence has a direct positive and significant impact on purchase intention}

The table 6 confirmed that social influence has a direct positive and significant impact on purchase intention. The $\mathrm{t}$ value is 2.18 which is higher than 1.96 and the p-value is 0.000 so the hypothesis 3 is accepted

\section{H4: Perceived risk has a strongly negative influence on purchase intention}

The table 6 confirmed that perceived risk has a direct positive effect on purchase intention. The $t$ value is 0.232 which is lower than 1.96 and the p-value is 0.816 so the hypothesis 3 is rejected.

Table 7 represents the path coefficients of the remaining structural path which are Perceived trust to Purchase intention, performance expectancy to perceived trust, effort expectancy to Perceived trust, perceived risk to Perceived trust, and social influence to Perceived trust. Based on the result we could conclude that all of the $t$ values have surpassed 1.96 except perceived risk and all $p$-values have values lower than 0.05 except perceived risk. On the other hand, the following other hypotheses could not be determined by only seeing the p-values yet after conducting the mediating test there will be the answers.

Table 7: p-values

\begin{tabular}{|c|c|c|c|c|c|}
\hline Structural path & $\begin{array}{l}\text { Original } \\
\text { Sample (O) } \\
\end{array}$ & $\begin{array}{l}\text { Sample } \\
\text { Mean }(M)\end{array}$ & STDEV & T Statistics & P-Values \\
\hline $\begin{array}{l}\text { Perceived trust -> } \\
\text { Purchase intention }\end{array}$ & 0.24 & 0.239 & 0.057 & 4.211 & 0.000 \\
\hline $\begin{array}{l}\text { Performance expect } \\
\text { > Perceived trust }\end{array}$ & 0.255 & 0.254 & 0.067 & 3.785 & 0.000 \\
\hline $\begin{array}{l}\text { effort expectancy -> } \\
\text { Perceived trust }\end{array}$ & 0.362 & 0.362 & 0.07 & 5.19 & 0.000 \\
\hline $\begin{array}{l}\text { perceived risk -> } \\
\text { Perceived trust }\end{array}$ & -0.068 & -0.065 & 0.045 & 1.519 & 0.129 \\
\hline $\begin{array}{l}\text { social influence -> } \\
\text { Perceived trust }\end{array}$ & 0.199 & 0.2 & 0.052 & 3.809 & 0.000 \\
\hline
\end{tabular}

\section{Direct, Indirect, and Total Effects}

To validate the mediation effect, this research uses the Bootstrapping method for non-parametric statistics. When the Bootstrap confidence interval does not contain 0, the direct, indirect, and total effects are combined. The Bootstrap technique was used 5,000 times in smartPLS.

Table 8: Total effects

TOTAL EFFECTS

Original Sample Sample Mean

(O) $\quad$ (M) STDEV Ttatistics P Values




\begin{tabular}{|c|c|c|c|c|c|}
\hline $\begin{array}{l}\text { Perceived trust }-> \\
\text { Purchase intention }\end{array}$ & 0.240 & 0.239 & 0.057 & 4.211 & 0.000 \\
\hline $\begin{array}{l}\text { Performance expectar } \\
\text {-> Perceived trust }\end{array}$ & 0.255 & 0.254 & 0.067 & 3.785 & 0.000 \\
\hline $\begin{array}{l}\text { Performance expectar } \\
\text {-> Purchase intention }\end{array}$ & 0.286 & 0.285 & 0.074 & 3.853 & 0.000 \\
\hline $\begin{array}{l}\text { effort expectancy -> } \\
\text { Perceived trust } \\
\text { effort expectancy -> }\end{array}$ & 0.362 & 0.362 & 0.07 & 5.19 & 0.000 \\
\hline $\begin{array}{l}\text { Purchase intention } \\
\text { perceived risk -> }\end{array}$ & 0.343 & 0.343 & 0.07 & 4.92 & 0.000 \\
\hline $\begin{array}{l}\text { Perceived trust } \\
\text { perceived risk -> }\end{array}$ & -0.068 & -0.065 & 0.045 & 1.519 & 0.129 \\
\hline Purchase intention & -0.007 & -0.003 & 0.043 & 0.157 & 0.875 \\
\hline $\begin{array}{l}\text { Social influence -> } \\
\text { Perceived trust }\end{array}$ & 0.199 & 0.200 & 0.052 & 3.809 & 0.000 \\
\hline $\begin{array}{l}\text { social influence -> } \\
\text { Purchase intention }\end{array}$ & 0.152 & 0.153 & 0.047 & 3.251 & 0.001 \\
\hline
\end{tabular}

Table 9: Indirect effects

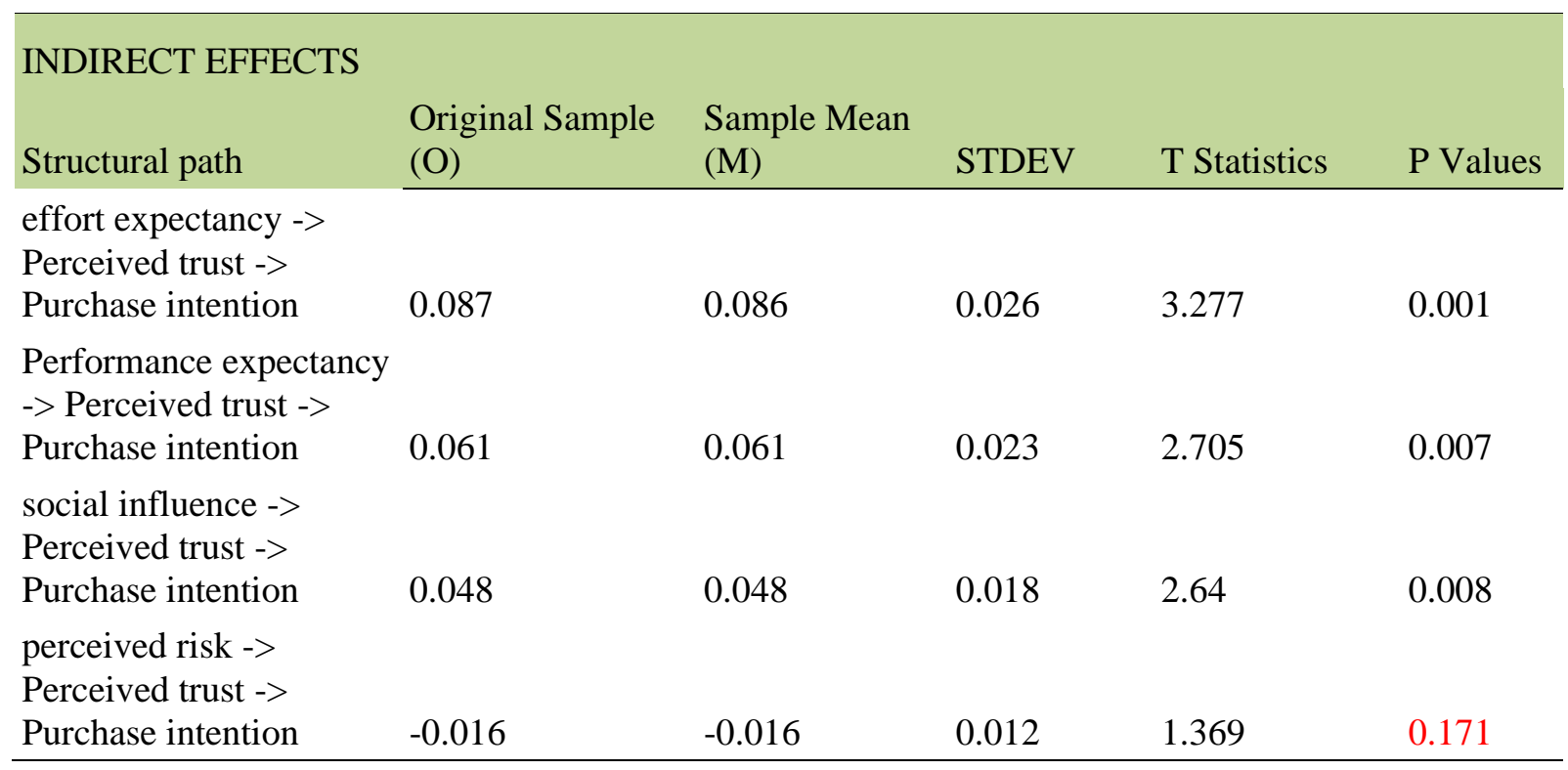

Table 8 above showing total effects and table 9 represents the indirect effects of the model. Redcolored ones are indicating insignificant since they have higher p-value than 0.05 , and the greencolored ones are significant reversely. Insignificant numbers which have negative value considered as not The original sample indicating the positive or negative they correlated to independent variables in a form of percentile. From the table we can see that :

i. $\quad$ Perceived trust positively affects purchase intention by $24 \%$ (direct effect)

ii. Performance expectancy positively affects purchase intention by $29 \%$ (direct effect)

iii. Effort expectancy positively affects purchase intention by $34 \%$ (direct effect)

iv. Social influence positively affects purchase intention by $15 \%$ (direct effect)

v. Performance expectancy positively affects perceived trust by $26 \%$ (direct effect)

vi. Effort expectancy positively affects perceived trust by $36 \%$ (direct effect)

vii. Social influence positively affects perceived trust by $20 \%$ (direct effect)

viii. Social influence positively affects purchase intention via perceived trust by $5 \%$ (Indirect 
effect)

ix. Performance expectancy positively affects purchase intention via perceived trust by $6 \%$ (indirect effect)

x. Effort expectancy positively affects purchase intention via perceived trust by $9 \%$ (indirect effect)

\section{H5: Perceived trust plays a significant mediator role between performance expectancy and purchase intention}

The table xx confirmed that performance expectancy positively influences perceived trust. Perceived trust significantly affects purchase intention. The indirect path from table $\mathrm{xx}$ of performance expectancy $\rightarrow$ perceived trust $\rightarrow$ purchase intention is also positively related. So, perceived trust is partially mediating performance expectancy to purchase intention. The author could finally confirm that $\mathrm{H} 5$ is accepted.

\section{H6: Perceived trust plays a significant mediator role between effort expectancy and purchase intention}

The table $\mathrm{xx}$ shows that effort expectancy positively affects perceived trust. Perceived trust significantly affects purchase intention. The indirect path from table $\mathrm{xx}$ of effort expectancy $\rightarrow$ perceived trust $\rightarrow$ purchase intention is also positively related. Hence, perceived trust is partially mediating performance expectancy to purchase intention and $\mathrm{H} 6$ is accepted.

\section{H7: Perceived trust plays a significant mediator role between social influence and purchase intention}

Table $\mathrm{xx}$ shows that social influence has a favorable impact on perceived trust. Perceived trust has a substantial impact on purchase intention, the indirect path from table $\mathrm{xx}$ of social influence $\rightarrow$ perceived trust $\rightarrow$ purchase intention is also significant. So, perceived trust partially mediating performance expectancy to buy intention and $\mathrm{H} 7$ is accepted.

H8: Perceived trust plays a significant mediator role between perceived risk and purchase intention Perceived risk has a negative impact and insignificant effect on perceived trust. Perceived trust significantly affects purchase intention. But based on their indirect effect, perceived risk $\rightarrow$ Perceived trust $\rightarrow$ Purchase intention has an insignificant and negative path. Thus, It can be inferred that there is no mediating effect and rejected null hypothesis in $\mathrm{H} 8$.

Table 10: Mediating and Hypothesis Results

\begin{tabular}{|c|c|c|c|c|c|c|c|c|c|}
\hline \multicolumn{10}{|c|}{ MEDIATING RESULTS AND HYPOTHESIS RESULTS } \\
\hline Hypothesis & $\begin{array}{l}\text { Structural path direct } \\
\text { effect }\end{array}$ & $\begin{array}{l}\text { structural path a } \\
\text { (independent --> } \\
\text { mediator) }\end{array}$ & $\begin{array}{l}\text { effect (from } \\
\text { path } \\
\text { coefficient) } \\
\end{array}$ & $\begin{array}{l}\text { decision } \\
\text { from } \\
\text { p-value }\end{array}$ & Structural path & \begin{tabular}{|l} 
effect \\
(from \\
path \\
coefficie \\
nt) \\
\end{tabular} & $\begin{array}{l}\text { decision } \\
\text { from p-value }\end{array}$ & Mediation type & Decision \\
\hline $\mathrm{H} 5$ & $\begin{array}{l}\text { Performance expectancy } \\
->\text { Purchase intention }\end{array}$ & \begin{tabular}{|l} 
Performance \\
expectancy -> \\
Perceived trust
\end{tabular} & positive & significant & \begin{tabular}{|l|} 
Performance \\
expectancy -> \\
Perceived trust \\
$->$ Purchase \\
intention \\
\end{tabular} & positive & significant & Partial mediation & Accepted \\
\hline $\mathrm{H} 6$ & $\begin{array}{l}\text { effort expectancy -> } \\
\text { Purchase intention }\end{array}$ & $\begin{array}{l}\text { effort expectancy } \\
->\text { Perceived trust }\end{array}$ & positive & significant & \begin{tabular}{|l|} 
effort \\
expectancy -> \\
Perceived trust \\
-> Purchase \\
intention
\end{tabular} & positive & significant & Partial mediation & Accepted \\
\hline H7 & $\begin{array}{l}\text { perceived risk -> } \\
\text { Purchase intention }\end{array}$ & \begin{tabular}{|l} 
perceived risk -> \\
Perceived trust
\end{tabular} & negative & insignificant & $\begin{array}{l}\text { perceived risk } \\
->\text { Perceived } \\
\text { trust -> } \\
\text { Purchase } \\
\text { intention }\end{array}$ & negative & insignificant & no mediation & Rejected \\
\hline H8 & $\begin{array}{l}\text { social influence -> } \\
\text { Purchase intention }\end{array}$ & $\begin{array}{l}\text { social influence }-> \\
\text { Perceived trust }\end{array} \mid$ & positive & significant & \begin{tabular}{|l|} 
social influence \\
$->$ Perceived \\
trust -> \\
Purchase \\
intention
\end{tabular} & positive & significant & Partial mediation & Accepted \\
\hline
\end{tabular}




\section{Implications}

\section{Performance Expectancy}

To increase Mahajasa's customer engagement, the company should be attached to the performance of the website, customer service, and the customer journey.. Mahajasa ought to foresee what pain points from relevant competitors that still could not be tackled such as service quality, service variety, and service time bound. It has to be understood that a quicker job, more precise result, and useful tools is the first to be concerned with consumers to have the intention to buy. Strengthen the quality of service, such as 24 hours customer service hotline or chatbot. The last suggestion is to regularly test and monitor the website performance through speed tests and frequently fixing errors and bugs.

\section{Effort Expectancy}

In this variable, the customer expectation should be : easy to learn, easy to use, clear transparency whether on transaction or customer workflow. Therefore, it could be concluded that in order to boost their intention to buy, Mahajasa should ensure that their product is currently have user friendly interface to ease the user experience, settle clear and easy customer journey, make sure that every step in their journey has satisfied them, and a chatbot that ready to answer difficulties experienced by customers.

\section{Social Influence}

Understanding that based on the result this hypothesis is true, Mahajasa should implement some marketing strategies to strengthen their position. Virality, positive experience through word of mouth, mass advertising on social media, and various promotions could be implemented. Promotions recommendations for Mahajasa are vouchers for repeat buyers to increase their retention and subscription program for those who frequently buy services through the website. Good review and testimonials from customers is also important to be shown in the website and social media. Respective potential customers would easily get triggered and ask from the testimonials giver about the experience he or she had with the website. Through this, customer engagement would possibly levitate as well as their purchase intention.

\section{Perceived Trust}

Perceived trust has a mediator role between performance expectancy, effort expectancy, social influence toward purchase intention. In this case, perceived trust could be the reason why customers have the intention to buy after having the expectation of usefulness, expectation of easy to use, and their surroundings to influence them. Indeed perceived trust helps them to have such behaviors since perceived trust has big significance according to the number shown. Herein, the author implies that because some customers already have trust in Mahajasa, it increases their expectations of the outcome as well as more in believing what the other said about Mahajasa so they have higher purchase intention.

\section{Conclusion}

Following the competition in Indonesian freelancing marketplace, Mahajasa is studied in this research. Mahajasa provides the platform to connect between clients and freelancers which focus on students, SMEs, and individuals. Run as a business since August 2020, Mahajasa has some revenue track records. Based on graph $\mathrm{xx}$, the revenue is still fluctuating and unpredictable. There are also some symptoms regarding purchase intentions that still remain unknown. To be able to compete, Mahajasa needs to examine which factors led their consumers to have the intention to buy, since the factors could finally predict future sales and strategies. Other reasons why this study must be conducted is that based on various studies, SMEs are reluctant to accept new technology as in Indonesia since most 
marketplaces are in the adoption stage. Therefore, it is urgent to measure the technology acceptance within the targeted market. In this study, the UTAUT framework (Venkatesh et al., 2003) is chosen due to its complexity of technology acceptance model which may cause higher result's accuracy. RQ1 : What factors influence consumers' purchase intention from freelance marketplace or freelance social media from the perspective of UTAUT model?

Instead of using the original UTAUT model from Venkatesh et al (2003), the author used a refined one by Chen et al (2021). From the perspective of the reference model, there are 4 main independent variables, 1 mediator variable, and 1 dependent variable. There are performance expectancy, effort expectancy, social influence, and perceived risk stands for independent variables. Perceived trust as mediator variable from all of the independent variables towards purchase intention which is the dependent variable.

PLS-SEM algorithm and bootstrapping method is conducted to see the path coefficients and testing the hypotheses. Performance expectancy, effort expectancy, and social influence are positively related and significantly influence the purchase intention. Meanwhile, perceived risk is negatively related and insignificant toward purchase intention. The other variable tested is perceived trust acts as mediating variable from all independent variables toward purchase intention. The results come out as follows : perceived trust partially mediating performance expectancy, effort expectancy, and social influence toward purchase intention, while there is no mediating effect of perceived trust from perceived risk toward purchase intention.

\section{References}

Abubakar, A. M., \& Shneikat, B. H. T. (2017). ELancing motivations. Online Information Review, 4l(1). https://doi.org/10.1108/OIR-09-2015-0306

Aguinis, H. and Lawal, S. O. (2013). ELancing: A review and research agenda for bridging the science-practice gap', Human Resource Management Review, 23(1), 6-17. doi: 10.1016/j.hrmr.2012.06.003.

Ailawadi, Kusum L., Donald R. Lehmann, and Scott A. Neslin (2001). Market Response to a Major Policy Change in the Marketing Mix: Learning from Procter \& Gamble's Value Pricing Strategy, Journal of Marketing, 65 (1), 44-61.

Aristi, Nina \& Pratama, Ahmad. (2021). The Roles of Freelance Marketplaces and Social Media in Facilitating Professional Services Online Gig Economy. Techno Com, 20. 122-133. 10.33633/tc.v20i1.4261.

Catherine, B. N., Geofrey, K. M., Moya, M. B., \& Aballo, G. (2017). Effort expectancy, performance expectancy, social influence and facilitating conditions as predictors of Behavioural Intentions to use ATMS with fingerprint authentication in Ugandan banks. Global Journal of Computer Science and Technology, 17(5).

Chen, L., Rashidin, M. S., Song, F., Wang, Y., Javed, S., \& Wang, J. (2021). Determinants of Consumer's Purchase Intention on Fresh E-Commerce Platform: Perspective of UTAUT Model. SAGE Open, 11(2). https://doi.org/10.1177/21582440211027875

Compeau, D., Higgins, C. A., \& Huff, S. (1999). Social cognitive theory and individual reactions to computing technology: A longitudinal study. MIS Quarterly: Management Information Systems, 23(2). https://doi.org/10.2307/249749

Davis, F. D., Bagozzi, R. P., \& Warshaw, P. R. (1989). User Acceptance of Computer Technology: A Comparison of Two Theoretical Models. Management Science, 35(8). https://doi.org/10.1287/mnsc.35.8.982

Davis, F. D., Bagozzi, R. P., \& Warshaw, P. R. (1992). Extrinsic and Intrinsic Motivation to Use Computers in the Workplace. Journal of Applied Social Psychology, 22(14). https://doi.org/10.1111/j.1559-1816.1992.tb00945.x

Doan, Thu-Trang. (2020). Factors affecting online purchase intention: A study of Vietnam online customers. Management Science Letters, 10. 2337-2342. 10.5267/j.msl.2020.3.001. 
Edelman intelligence \& Upwork. (2020, September). FREELANCE FORWARD 2020. assetsglobal.website-files.com. Retrieved June 19, 2021, from https://assets-global.websitefiles.com/5ece60393f5cbb1b2f25ef60/5f60b48411b19fb49de5f664_Upwork_2020_Freelance_F orward\%20(1).pdf

Fishbein, M., \& Ajzen, I. (1975). Chapter 1. Belief, Attitude, Intention, and Behavior: An Introduction to Theory and Research. In Reading, MA: Addison-Wesley.

Fornell, C. and Larcker, D.F., 1981. Evaluating structural equation models with unobservable variables and measurement error. Journal of marketing research, 18(1), pp.39-50.

French, J. R. P., \& Raven, B. (1959). The bases of social power in Studies in Social Power, D. Cardwright (ed.). Institute for Social Research, Ann Arbor, MI.

Gliem, J. a, \& Gliem, R. R. (2003). Calculating, Interpreting, and Reporting Cronbach's Alpha Reliability Coefficient for Likert-Type Scales,. 2003 Midwest Research to Practice Conference in Adult, Continuing, and Community Education, 1992. https://doi.org/10.1109/PROC.1975.9792

Hair, J. F., Hult, G. T. M., Ringle, C. M., \& Sarstedt, M. (2017). A Primer on Partial Least Squares Structural Equation Modeling (PLS-SEM). Second Edition. In California: Sage.

Henseler, J., Dijkstra, T. K., Sarstedt, M., Ringle, C. M., Diamantopoulos, A., Straub, D. W., et al. (2014). Common beliefs and reality about partial least squares: Comments on Rönkkö \& Evermann (2013). Organizational Research Methods, 17, 182-209.

Hu, L.-T., \& Bentler, P. M. (1998). Fit indices in covariance structure modeling: Sensitivity to underparameterized model misspecification. Psychological Methods, 3, 424-453.

Hulland, J. (1999). Use of partial least squares (PLS) in strategic management research: A review of four recent studies. Strategic Management Journal, 20(2). https://doi.org/10.1002/(sici)10970266(199902)20:2<195::aid-smj13>3.0.co;2-7

Jeng, D.J.-F., \& Tzeng, G.-H. (2012). Social influence on the use of clinical decision support systems: Revisiting the unified theory of acceptance and use of technology by the fuzzy DEMATEL technique. Computers \& Industrial Engineering, 62(3), 819-828. https://doi.org/10.1016/j.cie.2011.12.016

Kim, D.J., Ferrin, D.L., \& Rao, H.R. (2008). A trust-based consumer decision-making model in electronic commerce: The role of trust, perceived risk, and their antecedents. Decision Support Systems, 44(2), 544-564. https://doi.org/10.1016/j.dss.2007.07.001

Moore, G. C., \& Benbasat, I. (1991). Development of an instrument to measure the perceptions of adopting an information technology innovation. Information Systems Research, 2(3). https://doi.org/10.1287/isre.2.3.192

Oglethorpe, J., Monroe, B.K. (1994), Determinant of perceived health and safety risk of selected hazardous product and activities. Journal of Consumer Research, 28(2), 326-346.

Pavlou, P. A. (2003). Consumer acceptance of electronic commerce: Integrating trust and risk with the technology acceptance model. International Journal of Electronic Commerce, 7(3). doi: 10.1080/10864415.2003.11044275.

Syuhada, A. A., \& Gambett, W. (2013). Online Marketplace for Indonesian Micro Small and Medium Enterprises based on Social Media. Procedia Technology, 11. https://doi.org/10.1016/j.protcy.2013.12.214

Tench, R., Fawkes, J., \& Palihawadana, D. (2002). Freelancing: Issues and trends for public relations practice. Journal of Communication Management, 6(4), 311-322. https://doi.org/10.1108/13632540210807143

Thompson, R. L., Higgins, C. A., \& Howell, J. M. (1991). Personal computing: Toward a conceptual model of utilization. MIS Quarterly: Management Information Systems, 15(1). https://doi.org/10.2307/249443

Venkatesh, V., Morris, M. G., Davis, G. B., \& Davis, F. D. (2003). User acceptance of information technology: Toward a unified view. MIS Quarterly: Management Information Systems, 27(3). https://doi.org/10.2307/30036540

WR, J. W., \& Ariyanti, M. (2017). Perceived Factors Influencing Consumer Trust and Its Impact on Online Purchase Intention in Indonesia. International Journal of Science and Research, 6(8). 